\title{
CAPITAL ACCOUNT LIBERALISATION BY CHINA AND THE EFFECTS ON GLOBAL FDI AND TRADE
}

\author{
George Verikios \\ KPMG Economics \\ and \\ Department of Accounting, Finance and Economics, \\ Griffith University
}

\begin{abstract}
$\underline{\text { Abstract }}$
We model the partial liberalisation of the capital account by China using a dynamic computable general equilibrium model of the world economy. Our results indicate that a reduced capital controls on FDI would lead to a significant increase in FDI capital in China and a significant reduction in the cost of capital in China relative to the rest of the world. Further, we observe an increase in capital stocks in most regions, which benefits most regions in terms of GDP and GNP. The Chinese economy grows by $3.3 \%$ driven by a significant fall in the rental price of capital that, in turn, lowers domestic costs, causes a real depreciation of the exchange rate and thus increased exports relative to other regions. We also observe an across-the-board increase in the saving rate driven by the rise in the price of consumption relative to investment (saving) in all regions.
\end{abstract}

JEL codes: $\quad$ C68, E22, F21, F23, F38, F40.

Keywords: $\quad$ capital controls, China, computable general equilibrium, FDI, multinational firms, trade.

\section{Acknowledgements}

This work was supported by the United States International Trade Commission. The views expressed here are the author's and do not necessarily reflect those of KPMG Economics. Thanks go to Peter Dixon for extensive advice on this study, to Michael Kouparitsas for suggesting the research topic and Qiaomin Li and two anonymous referees for helpful comments on the paper. 


\section{Introduction}

Two important global macroeconomic policy issues that have emerged since the turn of the century are exchange rate flexibility and capital account liberalisation by China. Both of these issues have become more prominent since the Chinese economy became the second largest in the world in 2010. ${ }^{1}$ The Chinese authorities have stated publicly that the removal of capital controls is a medium-term objective (Prasad et al., 2005), but there is evidence that the removal of capital controls by developing countries can have significant macroeconomic effects (Sedik and Sun, 2012). Given this, what might be the likely nature and size of the macroeconomic effects of a move towards capital account liberalisation by the Chinese authorities? We address this question by applying an analytical framework that captures the most important macroeconomic features of this issue as they relate to global foreign direct investment (FDI) and trade.

China's capital account is tightly controlled (Jeanne, 2012) and the capital controls have tended to be more restrictive for volatile capital flows (e.g., portfolio investment) compared to more stable capital flows (e.g., FDI). The controls seem to have initially focused on restricting outflows but have evolved to manage both inflows and outflows so as to maintain the official exchange rate (Ma and McCauley, 2007). It is likely that this is a result of an increasing gap, over time, between the official exchange rate and the likely market exchange rate under a flexible exchange rate scheme. The large current account surpluses posted by China since 2005 suggest that the management of inflows has probably been more important than the management of outflows; this view is supported by the accumulation of enormous foreign exchange reserves by China. ${ }^{2}$ Since 2008 the size of the current account surpluses have fallen, capital outflows have increased and the exchange rate has experienced some downward pressure. Despite this, China's foreign exchange reserves are still enormous suggesting that the effect of capital controls is to control net inflows. If the management of net inflows has been the dominant role of capital controls since 2005, then this would have the effect of limiting arbitrage between the (Chinese) domestic cost of capital and global cost of capital. ${ }^{3}$ In fact, macroeconomic observers have

1 This is according to current price data in US\$ (IMF, 2014).

2 China's current account surplus has averaged 4.5\% of GDP between 2001 and 2013; more recently, the surplus has averaged 2.3\% of GDP between 2014 and 2016 (IMF, 2014; World Bank, 2018). China's foreign exchange reserves are the world's largest holdings and were in the order of US\$3 trillion at the end of 2016 (World Bank, 2018).

3 By 'cost of capital' we mean the average cost (return) of raising (investing) funds across asset classes, including bonds, equity (or shares), and physical capital. Changes in the return on bonds e.g., the interest rate, affect the return on other asset classes as investors seek to maximise the return on their investment portfolio. 
expressed the view that the capital controls have had the effect of creating a positive cost of capital differential between the domestic cost of capital in China and the world cost of capital (Ma and McCaualey, 2010; Prasad and Wei, 2005). There is also evidence that this differential has increased over time (Chen, 2012; Cheung and Herrala, 2014).

Thus, any move to remove or reduce capital controls by China would be expected to lead to a smaller positive cost of capital differential between China and the rest of the world as FDI and financial capital would be expected to flow into China from other countries to exploit the differential. Such inflows are likely to have direct macroeconomic consequences for China: an increase in the capital stock implying increased investment, in turn, implying higher productivity and GDP growth in the short-run and permanently higher levels of productivity and GDP in the long-run. Countries investing in China would likely experience increased income due to increased investment in China in an attempt to exploit the cost of capital differential. Therefore, a priori, we would expect capital flows between China and other countries to increase due to the relaxation of capital controls by China. But, we would also expect an increase in trade flows between China and other countries as higher GDP growth by China would mean an increased demand for imports and an increased supply of exports to other countries.

There are no existing studies examining how capital account liberalisation by China would affect global FDI, trade and other macroeconomic variables. Two related studies quantify the macroeconomic effects of China's internal and external policies. Song et al. (2014) use an overlapping generations model of China to analyse the effects of different aspects of China's monetary and structural policies, including capital controls, and their interaction with China's growth path and other variables. Bénassy-Quéré et al. (2011) use a two-country (China and the US) overlapping generations model to analyse the interaction of structural reforms under different policy regimes in China, including the partial liberalisation of capital controls. In both studies, capital controls are found to be important in determining how China and other economies react to structural reforms by China. One area to which the current study is distantly related is the literature on economywide evaluations of removing barriers to trade in services: a major share of trade in services occurs through FDI (see Christen et al., 2012, for a thorough review of this literature). These evaluations examine the removal of general or sector-specific barriers to FDI in China and many other countries, but they do not consider the impact of capital controls, or other macroeconomic policies, on FDI and trade. Thus, the current work represents a first in 
examining the effects of capital account liberalisation by China on global trade and FDI; it is also a first in examining these effects on a sectoral basis.

\section{China's capital account policy}

China has applied capital controls as part of its economic policy since 1949 (Cheung and Herrala, 2014). These controls did not attract much attention until the turn of this century, but China's high and sustained economic growth since 1980s has slowly increased attention on all aspects of its economic policies. ${ }^{4}$ Along with exchange rate flexibility, capital account liberalisation by China has emerged as an important global macroeconomic policy issue. These two issues are related but distinct (Prasad et al., 2005).

A move towards exchange rate flexibility and capital account liberalisation has been argued to pose risks to the Chinese financial sector by allowing outflows from the banking system in order to exploit foreign investment opportunities. Nevertheless, allowing greater exchange rate flexibility in the presence of capital controls will not expose China's underdeveloped financial system to dangerous risks as Chinese domestic banks are not heavily exposed to currency risk (Prasad et al., 2005). Furthermore, allowing greater exchange rate flexibility while maintaining capital controls does not require an immediate move to a freely floating rate (IMF, 2004). In contrast to the seemingly low risks associated with allowing greater exchange rate flexibility while maintaining capital controls, there is evidence that liberalising capital controls while maintaining exchange rate inflexibility has contributed to financial crises in developing economies (Prasad et al., 2005). ${ }^{5}$

While China's capital account is tightly controlled (Jeanne, 2012), the capital controls have tended to be more restrictive for volatile capital flows (e.g., portfolio investment) compared to more stable capital flows (e.g., FDI). The controls were also initially focused on restricting outflows, presumably to shield domestic banks from currency risk, but have evolved to manage both inflows and outflows so as to maintain the official exchange rate (Ma and McCauley, 2007). Jeanne (2012) and Reinhart and Tashiro (2013) show that control of the capital account (i.e., net capital inflows) and the official exchange rate (i.e., reserve accumulation) allow the current

\footnotetext{
4 According to current price data in US\$, the Chinese economy has grown from being $7 \%$ of the size of the US economy in 1990 to $56 \%$ in 2013 (IMF, 2014).

5 Related to this, the risk tolerance capacity of the financial system is also important in determining the effect of greater exchange rate flexibility on financial risks (Zhang et al., 2016). Liu et al. (2016) show that the interaction of insurance and credit markets in Chinese regions is also important for financial risks and economic growth.
} 
account balance to also be tightly controlled. The large current account surpluses posted by China since 2005 suggest that the management of inflows has probably been more important than the management of outflows; this view is supported by the accumulation of the world's largest holdings foreign exchange reserves. Macroeconomic observers have expressed the view that the capital controls have had the effect of creating a positive cost of capital differential between the domestic cost of capital in China and the world cost of capital (Ma and McCaualey, 2010; Prasad and Wei, 2005). Although the size of the current account surplus has fallen from 9.9\% of GDP in 2007 to $1.8 \%$ in 2016 (World Bank, 2018) reflecting increased capital outflows and downward pressure on the exchange rate, China's foreign exchange reserves remain the world largest at US\$3 trillion suggesting that the effect of capital controls is still to control net inflows. As such, the differential between the domestic cost of capital in China and the world cost of capital is likely still positive.

The Chinese authorities have stated publicly that the removal of capital controls is a medium-term objective (Cheung and Herrala, 2014; Prasad et al., 2005). Any move to remove or loosen the capital controls would be expected to lead to the reduction of the positive cost of capital differential between China and the rest of the world; foreign-sourced loanable funds within China would increase at the expense of loanable funds in the rest of the world. Given China's very high saving rate (around 50\%) and its status as the second-largest economy in the world, it is likely that the removal of capital account controls would also lead to other significant effects on global capital markets. A freer flow of capital between China and global capital markets is likely to lead to a substantial repatriation of foreign-currency assets (particular US dollar assets) held by Chinese residents. Clearly, this will raise yields on US dollar and other foreign currency assets, and reduce yields on renminbi-denominated assets in China. A freer flow of capital between China and global capital markets is also likely to lead to a redirection of funds from non-renminbi assets into renminbi assets in China to exploit their high relative yields (He and Sun, 2013). Both of these effects are will reduce the positive cost of capital differential between China and the rest of the world.

A smaller cost of capital differential between China and the rest of the world is likely to lead to direct macroeconomic consequences for China. A lower cost of capital in China, ceterus paribus, is likely to lead to an increase in the capital stock employed (i.e., capital deepening), which implies increased investment and faster growth in the capital stock that in turn implies higher productivity and GDP growth. A lower cost of capital for Chinese households is likely to 
lead to a rise in the consumption rate as Chinese households take on debt (or reduce saving) to increase current consumption and reduce future consumption. A rise in the consumption rate would be likely to increase imports and reduce exports: ${ }^{6}$ that is, a reduction in net exports. A fall in net exports, ceterus paribus, is likely to partially offset GDP growth in China, with the overall effect of the fall in the cost of capital likely to be positive for China's GDP growth.

A rise in the world cost of capital would also have implications for nations holding historically high levels of net foreign debt, e.g., most developed countries, as their servicing obligations would rise. An increase in servicing obligations would reduce the amount of income available for both consumption and investment. Lower investment would mean lower growth in capital and output, ceterus paribus, which would mean lower GDP growth.

The direct macroeconomic consequences described above are likely to have noticeable impacts on trade flows between China and highly indebted developed countries, but also on other countries. Beyond this, any fall in loanable funds available to highly indebted developed economies will also have implications for FDI as these same countries are also the major sources of FDI (Lakatos and Fukui, 2013). Thus, one way that FDI is financed by these regions is through foreign debt accumulation, as reflected by large and persistent current account deficits. If the supply of funds available to these countries decreases, it may mean a rise in FDI by these regions. If the cost of borrowing to fund all forms of investment rises, this may induce investors to transfer funds from less risky low return investments (e.g., portfolio investment and sovereign debt) to more risky high return investments such as FDI.

\section{The model}

In this study we apply a modified version of the USITC-FDI model (Lakatos and Fukui, 2013). The model represents the global economy within a computable general equilibrium framework with a focus on FDI, multinational companies differentiated by region of ownership, and global foreign affiliate data. The model has been modified in order to capture important elements of modelling liberalisation of China's capital account. Below we describe the production and demand structure of the model and the modifications made for this study. ${ }^{7}$

\footnotetext{
6 An increase in the consumption rate would mean higher domestic prices relative to world prices.

7 The model is implemented and solved using the GEMPACK economic modelling software (Harrison and Pearson, 1996).
} 


\subsection{Production technology}

Representative firms are assumed to treat the factors of production (labour and physical capital) as variable and take factor prices as given in minimising costs. Demands for primary factors are modelled using nested production functions consisting of two levels. At the top level, the $j(=1, \ldots, 6)$ firms located in the $r(=1, . ., 9)$ regions and owned by the $o(=1, . ., 9)$ regions decide on the (percentage change in) demand for the primary factor composite (i.e., an aggregate of labour and capital) $q_{j r o}^{F}$ using CES (constant elasticities of substitution) production technology: ${ }^{8}$

$$
q_{j r o}^{F}=q_{j r o}-\sigma\left(p_{j r o}^{F}-p_{j r o}\right) ;
$$

where $\sigma(=0.1)$ is the elasticity of substitution between the primary factor composite and intermediate inputs, $q_{j r o}$ is (the percentage change in) the $(j, r, o)$-th industry's activity level, $p_{j r}^{F}$ is the price of the primary factor composite, and $p_{j r o}$ is the price of output by the firm. ${ }^{9}$ Clearly, equation (1) consists of a scale term $\left(q_{j r o}\right)$ and a substitution term $\left(p_{j r o}^{F}-p_{j r o}\right)$. Thus, with no change in relative prices, changes in output will lead to changes in the demand for the primary factor composite. With output fixed, changes in relative prices will lead to changes in the demand for the primary factor composite; this effect will be larger the greater the value of $\sigma$. All of these effects reflect standard optimising behaviour by the firm.

At the second level, firms decide on their demand for the $i(=2)$ factors of production, $q_{i j r o}^{F}$, also using CES production technology:

$$
q_{i j r o}^{F}=q_{j r o}^{F}-\omega_{j}\left(p_{i j r o}^{F}-p_{j r o}^{F}\right) ;
$$

where $\omega_{j}$ is the elasticity of factor substitution and $\leq 0.5$ for all $j$ industries, and $p_{i j r o}^{F}$ is the price of the $i$-th primary factor. Like equation (1), equation (2) consists of a scale term and a substitution term. The value of $\omega_{j}$ is based upon parameter choices that have been extensively applied in other studies. ${ }^{10}$

\footnotetext{
${ }^{8}$ In the formal presentation of the model theory, we use lowercase Latin characters to represent the percentagechange form of a variable (e.g., $p$ ), and equivalent uppercase Latin characters to represent the levels form of a variable (e.g. $P$ ).

${ }^{9}$ In describing the production technology, we omit technical change terms to simplify the exposition.

10 See, for example, Adams et al. (2000), Dixon and Rimmer (2002), Dixon et al. (2011), Horridge et al. (2005) and Wittwer et al. (2005).
} 
Firms are also assumed to be able to vary the $k(=1, \ldots, 6)$ intermediate inputs they use in production, the prices of which they also take as given in minimising costs. In combining intermediate inputs, all firms are assumed to use nested production functions. At level 1, all firms decide on their use of the intermediate input composite $q_{k j r o}^{I}$ using CES production technology;

$$
q_{k j r o}^{I}=q_{j r o}-\sigma\left(p_{k j r o}^{I}-p_{j r o}\right)
$$

where $p_{k j r o}^{I}$ is the price of the $i$-th intermediate input composite. Equation (3) determines firms' use of the intermediate input composite as a function of scale and substitution terms.

At level 2, firms decide on their use of individual intermediate inputs from domestic $\left(q d_{\text {kjro }}^{I}\right)$ and imported $\left(q m_{\text {kjro }}^{I}\right)$ sources using CES production technology:

$$
\begin{aligned}
& q d_{k j r o}^{I}=q_{k j r o}^{I}-\zeta_{k}\left(p d_{k j r o}^{I}-p_{k j r o}^{I}\right), \\
& q m_{k j r o}^{I}=q_{k j r o}^{I}-\zeta_{k}\left(p m_{k j r o}^{I}-p_{k j r o}^{I}\right),
\end{aligned}
$$

where $p d_{\text {kjo }}^{I}\left(p m_{\text {kjro }}^{I}\right)$ is the price of the $k$-th domestic (imported) intermediate input composite, and $\zeta_{k}$ is the elasticity of substitution between domestic and imported commodities. The values for the CES at this level range over 2.3-3.3 for traded goods (i.e., agriculture, mining, and manufacturing), and over $0.1-0.5$ for nontraded goods (i.e., services).

All firms are assumed to operate in perfectly competitive markets and so a zero-pure-profits condition is imposed that equates revenues with costs, which in levels is

$$
P_{j r o} \cdot Q_{j r o}=P_{j r o}^{F} \cdot Q_{j r o}^{F}+\sum_{k} P_{k j r o}^{I} \cdot Q_{k j r o}^{I} \cdot
$$

\subsection{Market clearing and commodity preferences}

The model distinguishes multinational firms. Thus, production is distinguished by location (indexed by $r$ ) and owner (indexed by $o$ ). Thus, the supply price of the $(j, r, o)$-th industry $\left(P_{j r o}\right)$ is linked to the market price $\left(P M K T_{j r o}\right)$ via $P M K T_{j r o}=P_{j r o}\left(1+T_{j r o}\right)$, where $T_{j r o}$ is the output tax on the $(j, r, o)$-th industry. $P M K T_{j r o}$ is determined via a market-clearing condition, which in percentage-change form is

$$
q_{j r o}=S D_{j r o} \cdot q d_{j r o}+\sum_{s} S X_{j r o s} \cdot q x_{j r o s},
$$


where $q d_{j r o}$ is domestic sales of the $(j, r, o)$-th good (i.e., sales to firms, households and government), $q x_{j r o s}$ is export sales of the $(j, r, o)$-th good to region $s$, and the $S$ s are the relevant shares of domestic and export sales in total output.

Domestic sales across firms producing the $j$-th commodity $\left(q d_{j r o}\right)$ is determined by CES preferences as

$$
q d_{j r o}=q d_{j r}-\zeta_{j}\left(p m k t_{j r o}-p m k t_{j r}\right)
$$

where $q d_{j r}$ is domestic sales of the $j$-th good across all firms (i.e., across all owners), and $p m k t_{j r}$ is the average market price for good $j$ produced by all firms in region $r$.

Export sales of the $(j, r, o)$-th good across the $s$ regions is determined by CES preferences as

$$
q x_{j r o s}=q m_{j r}-\zeta_{j}\left(p x_{j r o s}-p m_{j r}\right),
$$

where $q m_{j r}$ is import sales of the $j$-th good in region $r$ by all agents (i.e., firms, households and government), and $\mathrm{pm}_{j r}$ is the average c.i.f. price for good $j$ imported by region $r$ from all source regions.

\subsection{Regional and sector-specific investment}

In original form, USITC-FDI assumes that there is a single investment good available for all sectors. This assumption is at odds with the assumption of sector-, location- and ownerspecific (physical) capital in the model. Thus, we modify the assumption of a single investment good by apportioning regional investment across sectors. Following the real business cycle literature (King and Rebelo, 1999), the apportionment uses capital stock shares in each region. Once regional investment data has been apportioned across sectors, it is necessary to determine how sectoral investment will determined in the model.

Sectoral investment by industry $j$ in region $r, I_{j r}$, is assumed to be a fixed ratio of sectoral capital, $K_{j r}$, with an adjustment via the shift term $F I_{r}$;

$$
\frac{I_{j r}}{K_{j r}}=F I_{r} .
$$

With $I_{j r}$ determined in (10), industry demands for the $k(=6)$ inputs to investment $I_{k j r}$ are determined by CES production technology; 


$$
i_{k j r}=i_{j r}-\sigma\left(p i_{k j r}-p i_{j r}\right) .
$$

where $p i_{k j r}$ is the (percentage-change in the) price of the $i$-th input to investment, and $p i_{j r}$ is the (percentage-change in the) average price of inputs to investment. Note that $p i_{j r}$ will vary across industries in a region, i.e., the price of investment is now sector-specific. Once $I_{k j r}$ has been determined, demands for inputs to investment between domestic and foreign sources is determined by CES production technology as applied in the original model (see, for example, equations (4)-(5)).

At the top level of the investment technology nest, regional investment $I_{r}$ is determined as a share of GDP with an adjustment for the relative rate of return on capital:

$$
\frac{I_{r}}{G D P_{r}}=\left(\frac{R O R_{r}}{R O R}\right)^{\varepsilon} F G_{r} .
$$

where $R_{O} R_{r}(R O R)$ is the post-tax net (of depreciation) rate of return on capital in the $r$-th region (globally), $\varepsilon(=0.5)$ is a positive parameter, and $F G_{r}$ is a shifter that ensures both sides of (12) are equal in the initial solution. To ensure consistency between $I_{r}$ and $I_{j r}$, we add an adding up constraint:

$$
I_{r}=\sum_{j} I_{j r}
$$

To ensure that equation (13) is consistent with equations (10) and (12), $F I_{r}$ in (10) is set as endogenous.

\subsection{Aggregate household consumption, government expenditure and saving}

The USITC-FDI model follows the GTAP model (Hertel and Tsigas, 1997) by allocating net (of depreciation) national income across aggregate government consumption, aggregate household consumption and net (of depreciation) saving to maximise a Cobb-Douglas utility function with variable scale and share parameters. Therefore, the nominal values of aggregate government consumption, aggregate household consumption and net (of depreciation) saving are almost fixed shares of nominal net national income. This treatment of household consumption is at odds with the life-cycle theory of consumption and saving, which predicts that changes in real wealth will influence household aggregate spending over and above any changes in current income or other factors. The policy issue analysed in this work is expected to lead to significant 
changes in real wealth, and in order to capture the effects of these changes on household consumption we implement a life-cycle theory of consumption and saving.

Following Dornbusch and Fisher (1978), we assume aggregate nominal household expenditure $(C)$ in a region moves with nominal household disposable income ${ }^{11}(H D Y)$ and real wealth $(R W)$ :

$$
C=[A P C \cdot H D Y+\alpha \cdot R W] F D,
$$

where $A P C$ is the average propensity to consume out of $H D Y, \alpha(=0.06)$ is a positive parameter that controls the average propensity to consume out of real wealth, and $F D$ is scaling factor that ensures that both sides of (14) are equal in the initial solution.

The above treatment of household consumption replaces the original treatment in USITCFDI, which also affects the treatment of government consumption and saving. Government consumption $(G)$ is now assumed to be a fixed share of $G D P$, in nominal terms. Thus, saving $(S)$ is now a residual, being the difference between GNP, or national income, and household consumption and government consumption. This means that the saving rate, $S / G N P$, is endogenous and is determined by equation (14), i.e., $1-(C+G) / G N P$.

\subsection{Wealth accumulation}

The USITC-FDI model is comparative-static. As we wish to be able to use the model in dynamic form, i.e., apply the model to forecast the evolution of each region's economy from today to some period in the future, we add dynamics to the model in the form of wealth accumulation. The derivation of the wealth accumulation mechanism and its explanation closely follows Dixon and Rimmer (2002, pp. 43-7).

In applying the model in dynamic form, we can simulate the evolution of regional and global economies between two points in time, e.g., 2013-2023. With such a simulation, there is only a single time period but its length is 10 years. Thus, any accumulation relationship over this 10-year period requires an assumption about how model variables evolve through the simulation period. Following Dixon and Rimmer (2002), we assume model variables growth smoothly over the period. This means that stock and flow values from 2013 are treated as parameters in the model and those for 2023 are treated as variables. Thus, we assume that each region's wealth accumulates over the period as:

\footnotetext{
11 This is household income from all sources minus income taxes.
} 


$$
W_{t+s+1}=W_{t+s}+N S_{t+s}, \quad s=0,1, \ldots, 9 .
$$

where $W_{t}$ is the value of wealth at the beginning of year $t$, and $N S_{t}$ is the value of net (of depreciation) saving during year $t$.

Equation (15) says that wealth at the beginning of year $t+s+1$ equals wealth at the beginning of the previous year plus net saving during year $t+s$. Equation (15) can be written in terms of $W_{t+\tau}$ as

$$
W_{t+\tau}=W_{t}+\sum_{s=0}^{\tau-1} N S_{t+s}
$$

Now assume that net saving grows smoothly over the simulation period, i.e.,

$$
N S_{t+s}=N S_{t}\left(\frac{N S_{t+\tau}}{N S_{t}}\right)^{s / \tau} .
$$

Let $t$ represent 2014 and $t+\tau$ represent 2023; (16) can then be written as

$$
W_{t+\tau}=W_{t}+\sum_{s=0}^{\tau-1} N S_{t}\left(\frac{N S_{t+\tau}}{N S_{t}}\right)^{s / \tau}+F W
$$

where $F W$ is a variable representing the preference for wealth accumulation. Note that $W_{t}$ and $N S_{t}$ in (18) are parameters and set to values from 2013.

\subsection{Wealth allocation across asset classes}

We define wealth for each regional investor as consisting of two assets: physical capital and bonds. Physical capital $(K)$ is already defined in USITC-FDI by industry $j$, location $r$, and owner $o: K_{j r o}$. In allocating wealth between physical capital and bonds, the choice refers to total capital owned by owner $o$ : $K_{o}=\sum_{j} \sum_{r} K_{j r o}$.

Here, bonds $(B)$ represent all forms of debt and equity financing, i.e., all financial assets and liabilities. ${ }^{12}$ Thus, bonds are calibrated for each region so they represent net foreign income on all assets other than physical capital; this is achieved by setting regional net income from bonds so that the capital account balance matches observed values. ${ }^{13}$ In this way, bonds (i) allow the capital account to be closed, and (ii) give investors a choice of two types of assets in which to

12 This treatment of bonds is originally due to McDougall (1993) but its application here more closely follows Hanslow et al. (1999).

13 Such data is available from McDougall et al. (2012). 
invest their saving, with bonds representing a lower risk investment, and typically a lower return investment, than FDI. The inclusion of bonds thus represents investor choices and global capital markets more realistically than would otherwise be the case. As bonds represent a composite of all financial assets, they are modelled as net stocks for each region.

In allocating wealth between physical capital and bonds, each regional investor chooses $K_{o}$ and $B_{o}$ so as to maximise $\left[K_{o} \cdot R K_{o}-V D_{o}+B_{o} \cdot R B\right]$ subject to $Q W_{o}=C E T\left[K_{o}, B_{o}\right]$, ${ }^{14}$ where CET[.] is a constant elasticity of transformation utility function (Powell and Gruen, 1968), $R K_{o}$ is the average post-tax rental price of capital received by investor $o, R B$ is the global bond rate, and $Q W_{o}$ is real wealth of investor $o . V D_{o}=\sum_{j r} K_{j r o} . P I_{j r} . D_{j r}$ : i.e., the value of depreciation of capital owned by investor $o$, where $D_{j r}$ is the depreciation rate on capital used by industry $j$ in region $r$.

Thus, investors seek to maximise returns on wealth, which comprises (i) post-tax returns on capital net of depreciation $\left(K_{o} \cdot R K_{o}-V D_{o}\right)$, plus (ii) returns on bonds $\left(B_{o} \cdot R B\right)$, given $R K_{o}, P I_{j r}$ and $R B$. Note that returns on bonds could be positive or negative depending on the initial value of $B$ : thus $\sum_{o} B_{o}=0$. Note also that there is only a single bond rate as we assume perfect international arbitrage in the bond rate.

The maximisation problem for investors yields the following behavioural equations in percentage-change form:

$$
\begin{gathered}
k_{o}=q w_{o}-\gamma\left(\operatorname{ror}_{o}-\operatorname{ror}_{o}\right)+f k_{o}, \\
q b_{o}=q w_{o}-\gamma\left(C D_{o} . r b-r o r w_{o}\right)+f b_{o} ;
\end{gathered}
$$

where $k_{o}\left(q b_{o}\right)$ is the quantity of capital (bonds) owned by region $o$, ror is the post-tax net (of depreciation) rate of return on capital in region $o$, and rorw $w_{o}$ is the average rate of return on wealth in region $o . \quad \gamma(=-5)$ is a parameter controlling the degree of transformation between capital and bonds. $f k_{o}$ and $f b_{o}$ are terms representing preferences to hold wealth in the form capital and bonds.

14 As $B_{o}$ can take a negative value, the representation of the constraint as $Q W_{o}=C E T\left[K_{o}, B_{o}\right]$ is not strictly correct. In equation (20), this potential problem is handled via the coefficient $C D_{o}$. 
Equations (19)-(20) comprise scale and transformation terms. The scale term is determined by real wealth in region $o\left(q w_{o}\right)$ : this is nominal wealth $\left(w_{o}\right)$ deflated by the wealth price index. The transformation terms are a function of the relative rate of return of each asset class and the transformation parameter. Note the coefficient $C D_{o}$ for the equation determining the quantity of bonds. $C D_{o}=1$ for $B_{o}>0$ and $C D_{o}=-1$ for $B_{o}<0$; for no region is $B_{o}=0$. This coefficient makes $q b_{o}$ rise (fall) with $\left(r b-r o r w_{o}\right)$ if a region is a net creditor (debtor), i.e., they will lend (borrow) more (less).

\subsection{Capital supply across locations and industries}

Once capital by owner $\left(K_{o}\right)$ has been determined at the top level of the asset supply nest, it remains for capital to be allocated across the $r$ regional locations and the $j$ industries within those locations: $K_{j r o}$. These choices are determined by assuming that capital moves such to ensure that net after-tax rates of return are exogenous at baseline levels. Thus, $K_{j r o}$ is perfectly elastic at net initial after-tax rates of return.

\subsection{Capital mobility}

Having determined $K_{j r o}$, we define capital supply by industry $j$ in region $r$ across all owners: $K_{j r}=\sum_{o} K_{j r o}$. We also define capital demand by industry $j$ in region $r$ across all owners: $Q_{j r}^{K}=\sum_{o} Q_{i j r o}^{F}, i$ (= capital). By defining a market-clearing condition by industry and region, $K_{j r}=Q_{j r}^{K}$, we define a rental price of capital that is common to all owners of capital in the $(j, r)$-th industry: $P_{j r}^{K}$. Thus, any change that causes a fall in the price of capital for any supplier of capital to the $(j, r)$-th industry will reduce the price of capital for all owners of capital in the $(j, r)$-th industry. For example, if a supplier or group of suppliers increase their supply of capital to a given regional industry relative to the demand for capital, then all other suppliers of capital to the industry will experience a fall in their rental price. In this way, any cost-reducing technical change experienced by one capital supplier is transferred to all other suppliers in the same regional industry.

Consistent with this treatment of rental prices by industry, in the initial data we set net rates of return to capital to be equal across all suppliers of capital to a regional industry. Thus, rates of 
return vary across industries within a region, but they do not vary across owners of capital within the same industry in a region.

\subsection{Labour supply and labour-market clearing}

We define a labour supply function in each region as a function of population and the posttax real wage. We make labour supply sensitive to the real wage consistent with international evidence on non-zero wage elasticities of labour supply (e.g., Bargain et al., 2011). Thus, in each region $r$ we define the ratio of the labour supply $L S_{r}$ to population $P O P_{r}$ as

$$
\frac{L S_{r}}{P O P_{r}}=\left(P R W_{r}\right)^{\beta} A_{r}
$$

where $P R W_{r}$ is the post-tax real wage received by labour in region $r$ and $A_{r}$ and $\beta$ are positive parameters. Thus, labour supply is a positive function of the real wage and population. We set the labour supply elasticity $\beta=0.2$, making labour supply only slightly responsive to real wage in each region. $A_{r}$ is a scaling factor that is set to ensure equality between each side of (21) in the initial solution of the model.

In original form USITC-FDI assumes the aggregate demand of labour in each region $L D_{r}$ is exogenous. With $L S_{r}$ now defined in (21), we make $L D_{r}$ endogenous and add the labourmarket-clearing condition

$$
L S_{l r}=L D_{l r}
$$

Equation (22) now determines the pre-tax wage received by labour in region $r W_{r}$ by equating labour demand and supply.

\subsection{Regional income}

With each region earning foreign income it is necessary to redefine regional income to reflect the difference between economic activity within a region, i.e., GDP, and income earned by the region, i.e., GNP. GDP in location $r$ from the supply side and the demand side is defined as

$$
G D P_{r}=L Y_{r}+K Y_{r}+I T_{r}=C_{r}+I_{r}+G_{r}+X_{r}-M_{r},
$$

i.e., the sum of labour income $\left(L Y_{r}\right)$, capital income $\left(K Y_{r}\right)$ and indirect tax receipts $\left(I T_{r}\right)$ equals the sum of consumption $\left(C_{r}\right)$, investment $\left(I_{r}\right)$, government expenditure $\left(G_{r}\right)$ and net 
exports $\left(X_{r}-M_{r}\right)$. Note that $K Y_{r}=\sum_{j} \sum_{o} K Y_{j r o}: K Y_{r}$ includes capital income earned in the all industries by all investors. Also note that $K Y_{r o}=\sum_{j} K Y_{j r o}$ for $r=o$ is capital income earned on domestically-owned capital in region $r$, and $K Y_{r o}=\sum_{j} K Y_{j r o}$ for $r \neq o$ is capital income earned on foreign-owned (or FDI) capital in region $r$.

Regional income is then defined as

$$
G N P_{r}=G D P_{r}+F K Y_{r}-F K P_{r}+N I N T_{r} .
$$

That is, GDP plus capital income on FDI received by region $r\left(F K Y_{r}\right)$, minus capital income paid on FDI in region $r\left(F K P_{r}\right)$, plus net interest receipts on bonds for region $r\left(N I N T_{r}\right)$.

\section{The baseline}

The USITC-FDI model data is based on version 8 of the GTAP database that represents the world economy in 2007. In order simulate the policy change from a more recent representation of the world economy, we update the model database to a more recent year for which all historical data is available: 2013. This is the first step of the baseline. The second step of the baseline is to forecast the model into future. ${ }^{15}$

In step 1 model variables are updated from 2007 to 2013 by applying observed movements in GDP, population, consumer prices, and saving and investment ratios to GDP. The historical data is taken from the IMF's World Economic Outlook publication. ${ }^{16}$ The objective of this step is to ensure the model data conforms approximately to the pattern of global economic activity in 2013. Therefore, this step is not intended to strictly represent historical movements in global economic activity but to ensure we have a representation of the global economy in 2013 that conforms approximately to independent sources (i.e., the IMF), and to use that representation to conduct the policy simulations. In step 2 the model is projected forward by 10 years to 2023 using IMF forecasts for GDP, population and consumer prices.

\section{The effects of China partially liberalising the capital account}

Section 2 described that macroeconomic observers have expressed the view that China's capital account controls have had the effect of creating a positive cost of capital differential

\footnotetext{
15 More details on the baseline are available in Verikios (2015).

16 See http://www.imf.org/external/pubs/ft/weo.
} 
between China and the rest of the world. The initial rates of return for 2013 in our model are consistent with this view. Figure 1 shows that the global average rate of return is around 9\% whereas in China it is around $14 \%$; so there is a 5 percentage point gap between the rate of return in China and the global average. Figure 1 also shows that, as expected, high-income countries with open capital accounts and flexible exchange rates have the lowest rates of return: USA, Japan, Aust/NZ (Australia and New Zealand) and EU27.

Figure 1. Initial (2013) post-tax net rates of return by locationa

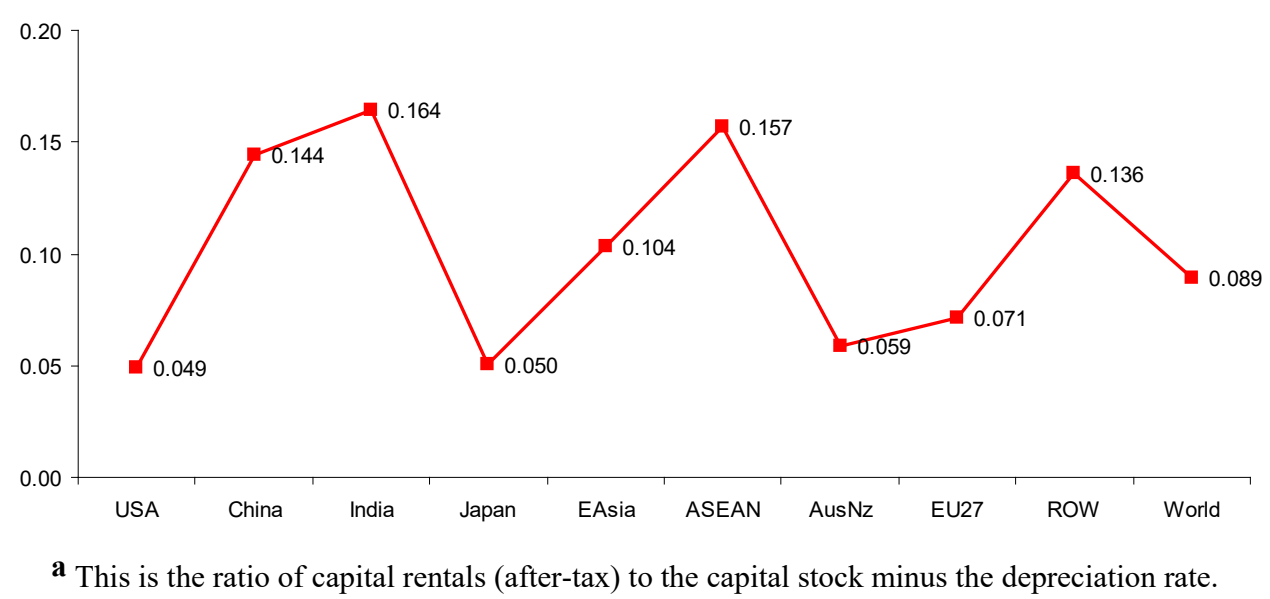

A priori, partial or complete removal of capital controls by China would be expected to lead to an influx of FDI and other capital with the intention of exploiting the high relative rate of return. The literature discussed in Section 2 supports the idea that capital controls have restricted inflows more that outflows. Such an influx would reduce the gap between the rate of return in China and the global average. Further, as we assume that the rental price of capital in each regional industry is the same for all suppliers of capital to that industry, any influx of FDI into China will reduce the rate of return for all suppliers of capital in each industry, including domestic suppliers. In this way, increased FDI automatically brings with it benefits to the domestic industry in terms of a lower cost of capital and higher productivity.

The literature provides little guidance on the degree to which the rate of return in China would fall relative to the global average by partial or complete removal of capital controls by China. Nevertheless, we would not expect the complete elimination of the rate of return gap even with complete capital liberalisation as the relatively high rates of return in China would reflect more than just the tightly controlled capital account. For instance, although China's economy is the second largest in the world its GDP per capita is still less than some developing countries, 
e.g., Mexico. Given this relatively low level of output per capita, one would expect that there would still be many unexploited investment opportunities within such an economy, and this would be consistent with a high relative rate of return. Thus, we would expect only a partial elimination of the gap between rates of return in China and globally even with the complete removal of capital controls in China. From a political economy perspective, the literature does suggest that complete capital account liberalisation by China is unlikely in the medium term unless it also abandons nominal exchange rate targeting.

Given the above discussion, we simulate the partial liberalisation of China's capital account by increasing the preference for other countries to locate FDI in China. We define this shock so as to ensure that these preferences sum to zero, as follows:

$$
K_{j r o}=\frac{P R_{r o}}{P R_{o}} F_{j r o} \text { where } P R_{o}=\sum_{r} S K_{r o} . P R_{r o} .
$$

$P R_{r o}$ is the preference for region $o$ to invest in region $r, S K_{r o}$ are the FDI shares of region $o$ investing across the $r$ destination regions, and $F_{j r o}$ is a shift variable. Equation (25) scales down the increase in $K_{j r o}$ to ensure no overall change in FDI capital by region $o$. To apply a shock to $P R_{r o}$ we endogenise the rate of return on FDI capital.

Capital controls are non-tariff barriers and, as such, we model their reduction by increasing the preference for all regions to invest FDI in China at initial rates of return. This is equivalent to an outward shift of the supply curve for capital in China (see Figure 2). The initial equilibrium is at the intersection of $\mathrm{S}_{0}$ and $\mathrm{D}_{0}$ giving an initial rental price of $\mathrm{R}_{0}$ and capital stock of $\mathrm{K}_{0}$. We model the removal of capital controls in China as they relate to FDI as a shift from $\mathrm{S}_{0}$ to $\mathrm{S}_{1}$, representing an increased preference to invest in China by the distance $\mathrm{K}_{S}-\mathrm{K}_{0}$. As drawn in Figure 2 , this would lead to a fall in the rental price to $\mathrm{R}_{1}$ and an increase in the capital stock to $\mathrm{K}_{1}$. Thus, our simulations should show a fall in the rate of return and an increase in the capital stock in China.

Initially we increase the preference to invest in China at initial rates of return by $50 \%$ in order to observe the pattern of effects we might occur. Subsequently we simulate preference increases of $100 \%$ and $200 \%$. In all our simulations we observe a reduction in the rate of return in China relative to the global average: larger increases in preferences lead to larger reductions in the rate of return in China relative to the global average. 
Figure 2. An increase in the supply of capital in China

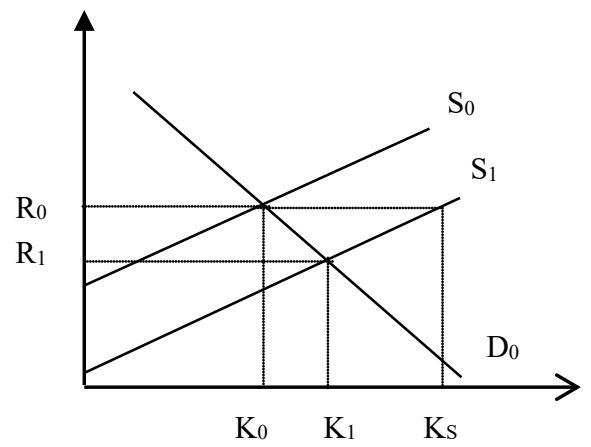

The above discussion has assumed that partial or complete removal of capital controls by China would be expected to lead to an influx of FDI and other capital with the intention of exploiting the high relative rate of return., reflecting the idea that capital controls have restricted inflows more that outflows. This is consistent with events up to 2008. However, since 2008 the capital account surplus has shrunk considerably as capital outflows (and capital inflows) have increased. The analysis here does not reflect this more recent behaviour in China's capital flows but it could be appropriately modified to model increased capital inflows and outflows.

\subsection{Capital allocation effects}

Table 1 shows how the allocation of capital across locations and owners is affected by the policy change; note that diagonal cells represent domestically-owned capital and off-diagonal cells represent FDI capital. All regions increase their (FDI) capital in China with increases in the order of $40 \%$ for all regions except East Asia and ASEAN, which increase in the order of $30 \%$. In general, the size of the response for each region is inversely related to the importance of FDI capital located in China relative to total FDI capital by the region. East Asia and ASEAN have the highest shares of FDI capital in China at over 20\% whereas other regions have shares at 10\% or less. As predicted by the partial-equilibrium analysis of Figure 2, the responses by regions investing in China are less than the increase in preferences for investing in China $(50 \%)$ as the preference shock is adjusted by equation (25) to reflect the initial importance of FDI capital located in China for each region. 
Table 1. Capital allocation effects of partial liberalisation of China's capital accounta (percentage change)

\begin{tabular}{|c|c|c|c|c|c|c|c|c|c|c|}
\hline \multirow{2}{*}{$\begin{array}{l}\text { Capital } \\
\text { location }\end{array}$} & \multicolumn{10}{|c|}{ Capital owner } \\
\hline & USA & China & India & Japan & East Asia & ASEAN & Aust/NZ & EU27 & $\begin{array}{l}\text { Rest of } \\
\text { World }\end{array}$ & TOTAL $^{\mathbf{b}}$ \\
\hline USA & 0.0 & -0.1 & 0.1 & 0.1 & 0.0 & 0.0 & 0.0 & 0.1 & 0.0 & 0.1 \\
\hline China & 44.1 & 0.4 & 40.3 & 44.6 & 33.5 & 31.2 & 42.6 & 42.5 & 44.6 & 5.9 \\
\hline India & 0.1 & 0.1 & 0.1 & 0.2 & 0.2 & 0.2 & 0.2 & 0.1 & 0.1 & 0.1 \\
\hline Japan & 0.0 & 0.2 & 0.2 & 0.1 & 0.2 & 0.2 & 0.2 & 0.0 & 0.2 & 0.1 \\
\hline East Asia & 0.0 & 0.0 & 0.2 & 0.0 & 0.0 & 0.1 & 0.3 & -0.1 & -0.1 & 0.0 \\
\hline ASEAN & 0.2 & 0.1 & 0.2 & 0.3 & 0.2 & 0.2 & 0.1 & 0.0 & 0.0 & 0.1 \\
\hline Aust/NZ & 0.1 & 0.1 & 0.1 & 0.1 & 0.0 & 0.1 & 0.1 & 0.0 & 0.2 & 0.1 \\
\hline EU27 & 0.1 & 0.1 & 0.1 & 0.1 & 0.2 & 0.1 & 0.1 & 0.1 & 0.1 & 0.1 \\
\hline Rest of World & 0.0 & 0.1 & 0.2 & 0.2 & 0.1 & 0.2 & 0.1 & 0.1 & 0.0 & 0.0 \\
\hline TOTAL & 0.8 & 0.4 & 0.1 & 0.3 & 2.6 & 0.9 & 0.8 & 0.8 & 0.2 & 0.6 \\
\hline
\end{tabular}

Source: Model simulation. a Diagonal cells represent domestically-owned and located capital and off-diagonal cells represent FDI capital. b Row totals represent total capital located in region $r$ : this is capital owned and located in region $r$ plus foreignowned capital located in region $r$. ${ }^{\mathbf{c}}$ Column totals represent total capital owned by region $r$ : this is capital owned and located in region $r$ plus capital owned by region $r$ but located in other regions.

The policy change leads to an increase in capital located in most regions (Table 1, last column). The total capital stock located in China (i.e., domestic- and foreign-owned) rises by $5.9 \%$ mainly due to higher FDI capital. All other regions experience marginal increases in the total capital stock. There is also an increase in capital owned by all regions (Table 1, last row). East Asia experiences the largest such increase (2.6\%). USA, ASEAN, Aust/NZ and EU27 experience smaller increases of around $0.8 \%$. Global capital rises by $0.6 \%$.

Physical capital and bonds represent the two asset classes owned by a region, and together they constitute wealth by region. Figure 3 shows that real wealth increases in all regions: the largest increases are in China (0.93\%), ASEAN (0.97\%) and EU27 (0.9\%). These regions experience increases in capital and increased lending to other regions (net bonds). The largest increase in capital is in East Asia (2.6\%) financed by a large increase in borrowing (16.1\%); thus real wealth only rises by $0.48 \%$. The net effect across all regions is an increase in real wealth of $0.19 \%$. The wealth accumulation mechanism (equation (18)) is a function of nominal net (of depreciation) savings over the period 2013-2023, which rises by about $0.67 \%$ globally. This reflects the rise in the saving rate in all regions; the rise in saving rates is driven by the global rise in the price of consumption relative to future consumption (i.e., investment): $-0.002 \% \mathrm{cf} .-0.13 \%$. The policy change has the effect of increasing the capital-labour ratio in most regions and thus reducing the price of capital relative to labour. As investment is more capital intensive than consumption, the price of investment (i.e., future consumption) falls relative to the price of 
current consumption and this encourages households to switch part of their income from current consumption to future consumption (i.e., saving).

Figure 3. Responses in real wealth, capital owned and net bonds (percentage change)

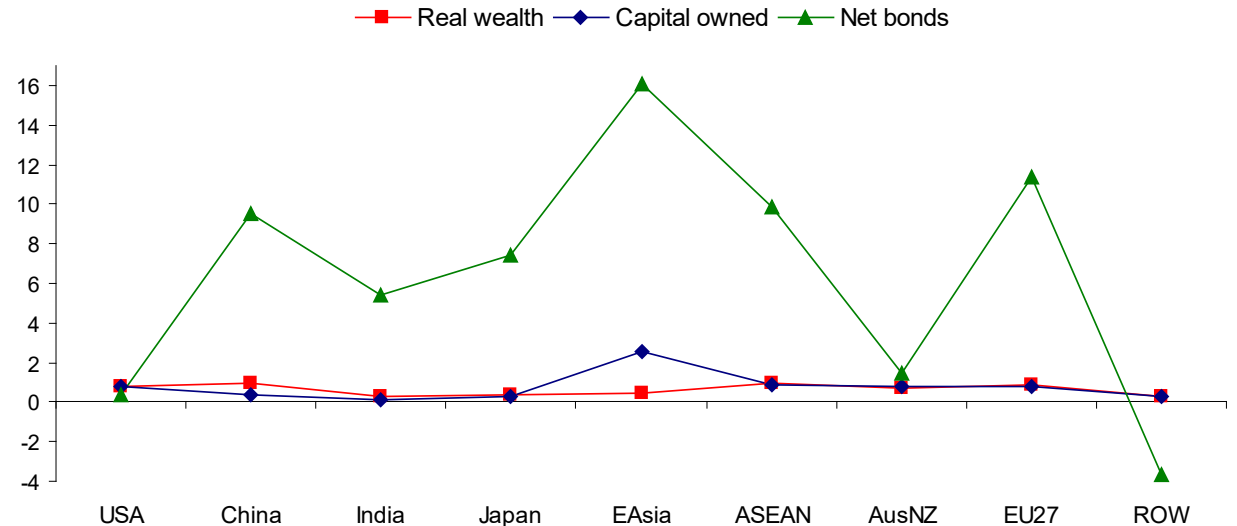

The growth in the global capital stock $(0.6 \%)$ drives down the global rate of return on capital $(-0.8 \%)$ (Table 2$)$. This reflects the fall in the rate of return earned on FDI capital in China by all non-China capital owners.

Table 2. Rate of return effects of partial liberalisation of China's capital accounta, b (percentage change)

\begin{tabular}{|c|c|c|c|c|c|c|c|c|c|c|}
\hline \multirow{2}{*}{$\begin{array}{l}\text { Capital } \\
\text { location }\end{array}$} & \multicolumn{10}{|c|}{ Capital owner } \\
\hline & USA & China & India & Japan & East Asia & ASEAN & Aust/NZ & EU27 & $\begin{array}{l}\text { Rest of } \\
\text { World }\end{array}$ & TOTAL \\
\hline USA & 0.0 & 0.0 & 0.0 & 0.0 & 0.0 & 0.0 & 0.0 & 0.0 & 0.0 & 0.0 \\
\hline China & -39.0 & 0.0 & -37.4 & -40.8 & -32.9 & -31.0 & -39.7 & -38.6 & -40.7 & -6.8 \\
\hline India & 0.0 & 0.0 & 0.0 & 0.0 & 0.0 & 0.0 & 0.0 & 0.0 & 0.0 & 0.0 \\
\hline Japan & 0.0 & 0.0 & 0.0 & 0.0 & 0.0 & 0.0 & 0.0 & 0.0 & 0.0 & 0.0 \\
\hline East Asia & 0.0 & 0.0 & 0.0 & 0.0 & 0.0 & 0.0 & 0.0 & 0.0 & 0.0 & 0.0 \\
\hline ASEAN & 0.0 & 0.0 & 0.0 & 0.0 & 0.0 & 0.0 & 0.0 & 0.0 & 0.0 & 0.0 \\
\hline Aust/NZ & 0.0 & 0.0 & 0.0 & 0.0 & 0.0 & 0.0 & 0.0 & 0.0 & 0.0 & 0.0 \\
\hline EU27 & 0.0 & 0.0 & 0.0 & 0.0 & 0.0 & 0.0 & 0.0 & 0.0 & 0.0 & 0.0 \\
\hline Rest of World & 0.0 & 0.0 & 0.0 & 0.0 & 0.0 & 0.0 & 0.0 & 0.0 & 0.0 & 0.0 \\
\hline TOTAL ${ }^{\mathbf{d}}$ & -1.1 & 0.0 & -0.1 & -0.4 & -3.5 & -0.9 & -1.1 & -1.1 & -0.3 & -0.8 \\
\hline
\end{tabular}

Source: Model simulation. a The rate of return is defined as the ratio of capital rentals (after-tax) to the capital stock minus the depreciation rate. $\mathbf{b}$ Diagonal cells represent the rate of return on domestically-owned capital and off-diagonal cells represent the

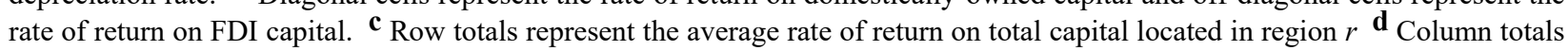
represent the average rate of return on total capital owned by region $r$ : this is capital owned and located in region $r$ plus capital owned by region $r$ but located in other regions. 
In its initial effect, the policy change does not favour any particular sector in China. Thus, as reflected in Table 3, capital in each sector expands by similar proportions. However, the capital stock increases slightly favour mining and manufacturing in China. Mining capital stocks also grow strongly in other regions where aggregate capital stocks grow strongly (East Asia and Aust/NZ); this reflects the capital-intensive nature of production of mining. Thus, mining benefits strongly when the relative price of capital falls in these regions. But unlike China, the increases in mining capital in East Asia and Aust/NZ are driven by mainly by an expansion in domestically-owned capital rather than FDI capital.

Table 3. Sectoral capital effects of partial liberalisation of China's capital account (percentage change)

\begin{tabular}{|c|c|c|c|c|c|c|c|c|c|}
\hline \multirow[b]{2}{*}{ Sector } & \multicolumn{9}{|c|}{ Location } \\
\hline & USA & China & India & Japan & East Asia & ASEAN & Aust/NZ & EU27 & $\begin{array}{l}\text { Rest of } \\
\text { World }\end{array}$ \\
\hline Agriculture & -0.03 & 5.19 & -0.02 & -0.19 & 0.37 & 0.02 & -0.04 & -0.12 & -0.07 \\
\hline Mining & -0.09 & 7.27 & -0.13 & -0.06 & 1.05 & 0.19 & 0.29 & -0.06 & -0.08 \\
\hline Manufacturing & -0.21 & 7.01 & -0.27 & -0.34 & 0.63 & -0.15 & -0.35 & -0.25 & -0.31 \\
\hline Trade & 0.06 & 5.48 & 0.16 & 0.19 & -0.25 & 0.26 & 0.06 & 0.12 & 0.09 \\
\hline Transport & 0.07 & 4.69 & 0.17 & 0.17 & 0.16 & 0.29 & 0.09 & 0.15 & 0.09 \\
\hline Other services & 0.12 & 5.27 & 0.33 & 0.18 & -0.32 & 0.37 & 0.17 & 0.15 & 0.24 \\
\hline
\end{tabular}

Source: Model simulation.

\subsection{Trade effects}

Table 4 presents the effects on sectoral and regional exports from the policy change. The effects largely mirror those already discussed for sectoral and regional capital stocks. Exports increase in regions that experience the largest increases in total capital - China $(6 \%)$ and East Asia (1.6\%) - and fall elsewhere. The large relative expansions in capital stocks in China and East Asia cause the rental price of capital to fall in these regions relative to other regions; this is reflected in the average price of primary factors presented in Table 4. With factor prices falling in China and East Asia relative to other regions, exports by China and East Asia rise relative to other regions and thus exports from these regions gain market share. 
Table 4. Export and primary factor price effects of partial liberalisation of China's capital account (percentage change)

\begin{tabular}{|c|c|c|c|c|c|c|c|c|c|}
\hline \multirow[t]{2}{*}{ Sector } & USA & China & India & Japan & East Asia & ASEAN & Aust/NZ & EU27 & $\begin{array}{l}\text { Rest of } \\
\text { World }\end{array}$ \\
\hline & \multicolumn{9}{|c|}{ Exports } \\
\hline Agriculture & 0.43 & 1.96 & -0.32 & -0.26 & 2.00 & 0.59 & 0.92 & 0.00 & 0.24 \\
\hline Mining & 0.10 & 7.94 & 0.66 & 0.70 & 2.61 & 0.40 & 0.75 & -0.04 & 0.04 \\
\hline Manufacturing & -0.68 & 6.47 & -1.59 & -0.84 & 1.77 & -0.28 & -0.76 & -0.50 & -0.85 \\
\hline Trade & 0.27 & 0.06 & 0.90 & 1.12 & 2.00 & 1.02 & 0.79 & 0.65 & 0.49 \\
\hline Transport & 0.30 & 1.47 & 0.17 & 0.38 & 0.82 & 0.38 & 0.42 & 0.31 & 0.26 \\
\hline Other services & 0.18 & 1.19 & 0.08 & 0.25 & 0.81 & 0.29 & 0.40 & 0.18 & 0.14 \\
\hline \multirow[t]{3}{*}{ TOTAL } & -0.40 & 6.00 & -1.03 & -0.52 & 1.58 & -0.11 & -0.06 & -0.23 & -0.45 \\
\hline & \multicolumn{9}{|c|}{ Average price of primary factors } \\
\hline & 0.11 & -1.04 & 0.33 & 0.15 & -0.36 & 0.08 & 0.10 & 0.09 & 0.15 \\
\hline
\end{tabular}

Source: Model simulation.

\subsection{Macroeconomic effects: GDP}

Table 5 presents the GDP effects of the policy change. GDP expands in almost all regions but China (3.3\%) experiences the largest increase; other regions experience minor increases. The GDP increases reflect the capital stock increases. The increases in capital relative to labour in most regions raise the marginal product of labour and thus the real wage. Increases in the real wage elicit an increase in the amount of labour supplied and thus employment. But the increases in labour are small relative to the increases in capital, i.e., the capital-labour ratio rises. The rise in the capital-labour ratio is consistent with fall in the rental-wage ratio observed in most regions.

Table 5. GDP effects of partial liberalisation of China's capital account (percentage change)

\begin{tabular}{|c|c|c|c|c|c|c|c|c|c|}
\hline Variable & $\overline{\text { USA }}$ & China & "India & "Japan & East Asia & ASEAN & "Aust/NZ & EU27 & $\begin{array}{c}\text { Rest of } \\
\text { World }\end{array}$ \\
\hline Labour & 0.01 & 0.95 & 0.04 & 0.02 & -0.02 & 0.05 & 0.02 & 0.01 & 0.02 \\
\hline Capital & 0.05 & 5.92 & 0.10 & 0.09 & -0.03 & 0.15 & 0.11 & 0.07 & 0.05 \\
\hline $\begin{array}{l}\text { Real exchange } \\
\text { rate }\end{array}$ & 0.22 & -1.28 & 0.35 & 0.35 & -0.16 & 0.21 & 0.24 & 0.10 & 0.19 \\
\hline Real wage & 0.05 & 4.79 & 0.21 & 0.11 & -0.11 & 0.23 & 0.09 & 0.07 & 0.12 \\
\hline Consumption & 0.02 & 4.20 & 0.19 & 0.15 & -1.38 & 0.21 & -0.07 & 0.08 & 0.08 \\
\hline Investment & 0.82 & 0.63 & 0.87 & 0.85 & 0.77 & 0.91 & 0.87 & 0.85 & 0.84 \\
\hline Exports & -0.40 & 6.00 & -1.03 & -0.52 & 1.58 & -0.11 & -0.06 & -0.23 & -0.45 \\
\hline Imports & 0.48 & 1.18 & 0.54 & 0.66 & 0.06 & 0.32 & 0.45 & 0.14 & 0.34 \\
\hline GDP & 0.03 & 3.31 & 0.08 & 0.05 & -0.03 & 0.11 & 0.06 & 0.05 & 0.05 \\
\hline
\end{tabular}

Source: Model simulation.

The pattern of capital responses also drives the response of the real exchange rate: the domestic output price relative to the price of output by trading partners. The real exchange rate 
depreciates in China and East Asia. Thus, domestic prices in China and East Asia fall relative to other regions. The real exchange rate depreciation leads to increased exports for China (6\%) and East Asia (1.6\%).

\subsection{Macroeconomic effects: GNP}

In the model, the difference between GDP and GNP is net foreign income. Net foreign income for region $r$ comprises: (i) income received from FDI capital owned by region $r$ and located abroad minus income paid on FDI capital located in region $r$ and owned by other regions; and (ii) interest receipts on net bonds. For most regions, net foreign income reinforces the GDP effect to give a larger GNP effect of the same sign (Table 6). The biggest difference between GDP and GNP is for East Asia: $-0.03 \%$ cf. $-0.71 \%$. For East Asia, net income on FDI capital makes a small positive contribution to GNP: 0.28 percentage points. But net bonds make a large negative contribution to GNP: -1.14 percentage points. This is because East Asia is a net borrower in the database and in response to the policy change they increase their borrowing $(16 \%)$ and the bond rate rises $(1.05 \%)$. For the same reasons, net bonds also make a negative contribution to GNP in Aust/NZ (-0.06 percentage points). All other regions experience positive or zero contributions to GNP from net bonds as they either reduce their borrowings (Rest of World) or increase their lending (all other regions).

Table 6. GDP and GNP effects of partial liberalisation of China's capital account (percentage change)

\begin{tabular}{|c|c|c|c|c|c|c|c|c|c|}
\hline Variable & USA & China & India & Japan & East Asia & ASEAN & Aust/NZ & EU27 & $\begin{array}{l}\text { Rest of } \\
\text { World }\end{array}$ \\
\hline GDP & 0.03 & 3.31 & 0.08 & 0.05 & -0.03 & 0.11 & 0.06 & 0.05 & 0.05 \\
\hline \multicolumn{10}{|l|}{ FDI capital } \\
\hline Owned $^{\mathbf{a}}$ & 0.70 & -0.01 & 1.31 & 0.64 & 1.95 & 2.55 & 0.70 & 0.86 & 0.61 \\
\hline Hosted $^{\mathbf{a}}$ & 0.06 & 6.26 & 0.11 & 0.05 & -0.03 & 0.10 & 0.06 & 0.11 & 0.05 \\
\hline $\mathrm{Net}^{\mathbf{c}}$ & 0.046 & -0.342 & 0.001 & 0.015 & 0.283 & 0.056 & 0.036 & 0.046 & 0.009 \\
\hline Net bonds $\mathbf{c}$ & 0.000 & 0.211 & 0.058 & 0.051 & -1.144 & 0.048 & -0.063 & 0.038 & 0.009 \\
\hline Bond rate & 1.05 & 1.05 & 1.05 & 1.05 & 1.05 & 1.05 & 1.05 & 1.05 & 1.05 \\
\hline GNP & 0.07 & 3.23 & 0.13 & 0.11 & -0.71 & 0.22 & 0.05 & 0.12 & 0.07 \\
\hline
\end{tabular}

For China, net FDI capital makes a negative contribution to GNP (-0.34 percentage points) because of the large increase in inward FDI relative to outward FDI: $6.3 \%$ cf. $-0.01 \%$. For all other regions, net FDI capital makes a positive contribution to GNP. For the large FDI exporters 
- USA, Japan and EU27 - net FDI capital rises because of the large increase in FDI located in China.

\section{Sensitivity analysis}

A priori, partial or complete removal of capital controls by China would be expected to lead to an influx of FDI and other capital with the intention of exploiting the high relative rate of return in China: the simulation results discussed above have demonstrated that, as expected, such an influx would reduce the gap between the rate of return in China and the global average. In the absence of guidance from the literature on the degree to which the rate of return in China would fall relative to the global average by partial or complete removal of capital controls by China, we have simulated a 50\% increase in other regions' preferences for investing in China at initial rates of return. Here we also present results for preference increases of $100 \%$ and $200 \%$.

Figure 4 shows that as the preference for investing in China increases, regional and global capital increases approximately linearly with a peak of $2.1 \%$ for the global capital stock. The results also show that in all three simulations there is a reduction in the rate of return in China relative to the global average: larger increases in preferences lead to larger reductions in the rate of return in China relative to the global average. Figure 5 also shows approximately linear changes in real GNP to varying increases in preference for investing in China; these effects peak at $10.6 \%$ for China. Thus our detailed results above provide a picture of the pattern of effects likely to eventuate from such a policy change regardless of the degree of liberalisation that is undertaken.

Figure 4. Capital stock response by location to different increases in preferences for investing in China (percentage change)

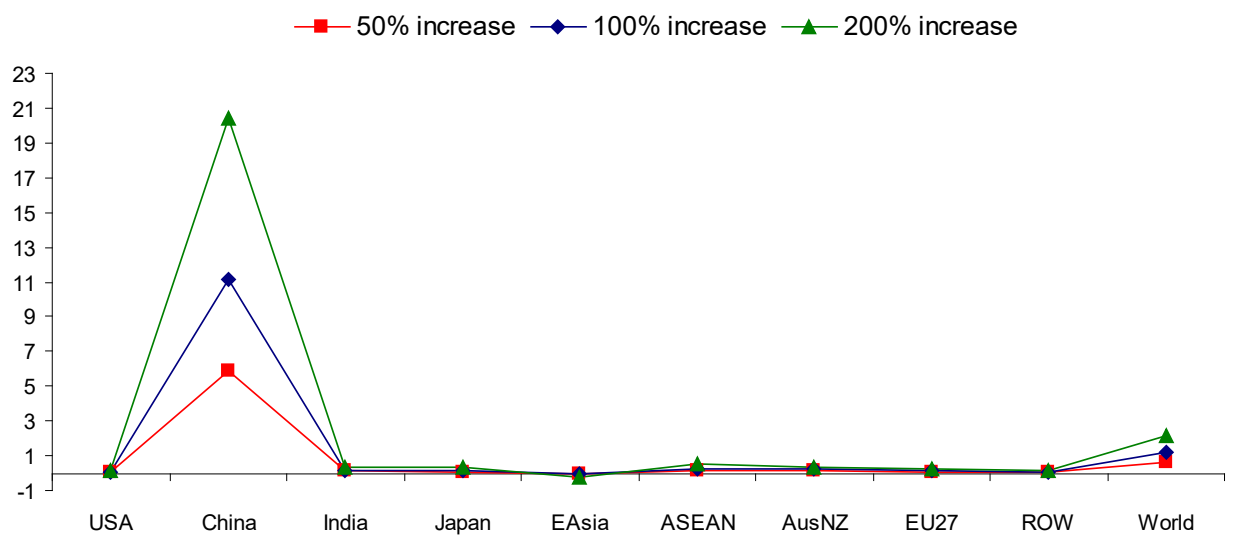


Figure 5. Real GNP responses to different increases in preferences for investing in China (percentage change)

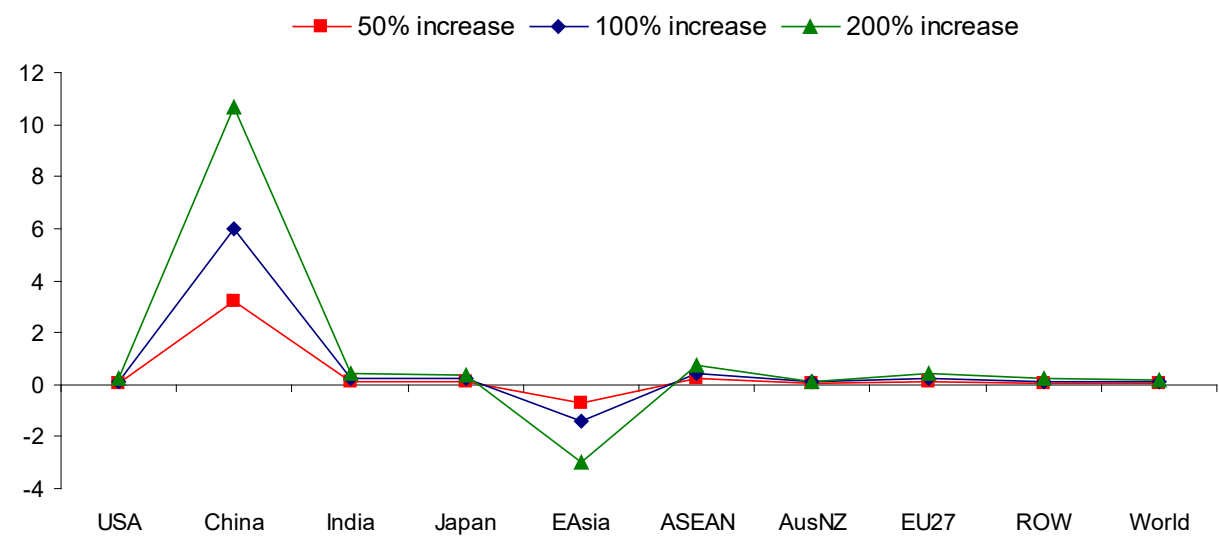

\section{Conclusion}

We model the partial liberalisation of the capital account by China using a dynamic computable general equilibrium model of the world economy. Specifically, we model the reduction of capital controls as they relate to foreign direct investment (FDI). The model incorporates many features to capture the salient macroeconomic effects of such a policy change; that is, multinational companies differentiated bilaterally by region of ownership and foreign affiliates, FDI capital stocks held by these firms, existing regional net debt positions, wealth accumulation through time, and a lifecycle approach to consumption and saving.

Our results indicate that a significant reduction of capital controls on FDI as reflected by a $50 \%$ increase in the preference for investing in China, would lead to an increase in FDI capital in China of $6.3 \%$. FDI capital would also increase in most other regions but by much smaller volumes. The large inflow of FDI into China lowers the rate of return on capital by $6.8 \%$ and the global rate of return by $0.8 \%$. Thus, we observe a significant reduction in the cost of capital in China relative to the rest of the world due to the reduction of capital controls; this result accords with the predictions of macroeconomic observers (Ma and McCaualey, 2010; Prasad and Wei, 2005). Sensitivity analysis indicates that the effects of the policy change are approximately linear in the size of the increase in the preference for investing in China: doubling the preference increase from $50 \%$ to $100 \%$ approximately doubles all effects for all regions.

In the central simulation where we simulate a $50 \%$ increase in the preference for investing in China, the fall in the global rate of return of capital reflects falling rental prices in China relative to other regions. The reduction in the rental price in China relative to other regions 
lowers domestic costs and causes a real depreciation of the exchange rate. Thus, exports from China gain market share.

The reduction of capital controls on FDI by China leads to an increase in capital stocks in most regions. This response benefits most regions in terms of GDP and GNP. The Chinese economy of China grows most strongly in response to this change $(3.3 \%)$. Other regions grow only marginally in response to the change: the results range between $0.03 \%$ and $0.11 \%$. The GNP effects generally mirror the GDP effects. The size of the GNP effect for each region reflects two effects: (i) the net change in FDI rentals on owned and hosted foreign capital, and (ii) the change in interest receipts on net bonds (i.e., debt instruments). All regions except China experience an increase in net FDI rentals as they exploit the higher rates of return in China through increased FDI; China experiences a decrease in net FDI rentals due to the large influx of FDI capital. Most regions experience positive or zero changes in net interest receipts as they either reduce their borrowings or increase their lending as the global bond rate rises by $1 \%$.

We observe an across-the-board increase in the saving rate. The shift from current to future consumption (saving) is driven by the rise in the price of consumption relative to investment (saving) that all regions experience. This reflects the fall in the relative of price of capital that occurs in all regions as investment is more capital intensive than consumption.

Our findings suggest that there are significant potential benefits for most regions from the reduction of capital controls on FDI inflows into China, but China itself is the major beneficiary of reducing such capital controls. Hence, the reduction or removal of such controls is in China's own economic interest but also in the interest of other regions. These results are consistent with the recommendations of macroeconomic observers in this area, e.g., Ma and McCaualey (2010); Prasad and Wei (2005). 


\section{References}

Bargain, O., Orsini, K. and Peich, A. (2011), 'Labor supply elasticities in Europe and the US', IZA Discussion Paper No. 5820, Institute for the Study of Labor, Bonn, June.

Bénassy-Quéré, A., Carton, B. and Gauvin, L. (2011), 'Rebalancing growth in China: an international perspective', CEPII Working Paper No. 2011-08, April.

CIA (Central Intelligence Agency) (2014), 'Reserves of foreign exchange and gold', in The World Factbook, https://www.cia.gov/library/publications/the-world-factbook/rankorder/2188rank.html.

Chen, J. (2012), 'Crisis, capital controls and covered interest parity: evidence from China in transformation', Paris School of Economics, Working Paper No. 2012-01.

Cheung, Y-W. and Herrala, R. (2014), China's capital controls: through the prism of covered interest differentials', Pacific Economic Review, vol. 19, no. 1, pp. 112-34.

Christen, E., Francois, J. and Hoekman, B. (2012), 'CGE modeling of market access in services', Working Paper No. 1208, Department of Economics, Johannes Kepler University of Linz, June.

Dixon P.B. and M.T. Rimmer (2002), Dynamic General Equilibrium Modelling for Forecasting and Policy: a Practical Guide and Documentation of MONASH, Contributions to Economic Analysis 256, North-Holland Publishing Company, pp. xiv+338.

Dornbusch, R. and Fisher, S. (1978), Macroeconomics, McGraw-Hill, New York.

Hanslow, K., Phamduc, T. and Verikios, G. (1999), 'The structure of the FTAP model', Research Memorandum MC-58, Productivity Commission, Canberra.

Harrison, W.J. and Pearson, K.R. (1996), 'Computing solutions for large general equilibrium models using GEMPACK', Computational Economics, vol. 9, no. 2, pp. 83-127.

He, Q., Sun, M. (2013), 'Does financial reform promote the inflow of FDI? Evidence from China's panel data', Global Economic Review, vol. 42, no. 1, pp. 15-28.

Hertel, T.W. and Tsigas, M.E. (1997), 'Structure of GTAP', Chapter 2, pp. 13-73 in Hertel, T.W. (ed.), Global Trade Analysis: Modeling and Applications, Cambridge University Press, Cambridge, UK.

IMF (International Monetary Fund) (2004), 'Peoples Republic of China: Article IV', Consultation Staff Report, IMF, Washington D.C.

IMF (2014), World Economic Outlook Database, October 2014, https://www.imf.org/external/pubs/ft/ weo/2014/02/weodata/index.aspx.

Jeanne, O. (2012), 'Capital account policies and the real exchange rate', NBER Working Paper 18404, Cambridge, Massachusetts, September.

King, R.G. and Rebelo, S.T. (1999), 'Resuscitating real business cycles', Chapter 14, pp. 927-1007 in Taylor, J.B. and Woodford, M. (eds.), Handbook of Macroeconomics, Volume 1, Elsevier Science, Amsterdam.

Lakatos, C. and Fukui, T. (2013), 'Liberalization of retail services in India: a CGE model', Office Of Economics Working Paper No. 2013-03A, U.S. International Trade Commission, Washington D.C.

Liu, G., Lee, C., He, L. (2016), 'The synergistic effects between insurance and credit markets on economic growth: evidence from China', Global Economic Review, vol. 45, no. 1, pp. 1-18.

Ma, G. and McCauley, R.N. (2007), 'Do China's capital controls still bind? Implications for monetary autonomy and capital liberalisation', Bank for International Settlements Working Papers No. 233, Basel, August.

McDougall, R. (1993), 'Incorporating international capital mobility into SALTER', SALTER Working Paper No. 21, Industry Commission, Canberra.

McDougall, R.A., Walmsley, T.L., Golub, A., Ianchovichina, E. and Itakura, K. (2012), 'An overview of the dynamic GTAP database: the data base construction and aggregation programs', pp. 120-35 in 
Walmsley, T.L. and Ianchovichina, E. (eds.), Dynamic Modeling and Applications for Global Economic Analysis, Cambridge University Press, Cambridge.

Powell, A.A. and Gruen, F.H.G. (1968), 'The constant elasticity of transformation production frontier and linear supply system', International Economic Review, vol. 9, no. 3, pp. 315-28.

Prasad, E., Rumbaugh, T. and Wang, Q. (2005), 'Putting the cart before the horse? Capital account liberalization and exchange rate flexibility in China', China \& World Economy, vol. 13, no. 4, pp. 320.

Prasad, E. and Wei, S-J. (2005), 'China's approach to capital inflows: patterns and possible explanations', IMF Working Paper WP/05/79, Washington D.C.

Reinhart, C.M. and Tashiro, T. (2013), 'Crowding out redefined: the role of reserve accumulation', NBER Working Paper 19652, Cambridge, Massachusetts, November.

Sedik, T.S. and Sun, T. (2012), 'Effects of capital flow liberalization-What is the evidence from recent experiences of emerging market economies?', IMF Working Paper, Washington D.C., November.

Song, Z., Storesletten, K. and Zilibotti, F. (2014), 'Growing (with capital controls) like China', IMF Economic Review, vol. 62, no. 3, pp. 327-70.

The World Bank (2018), Data Catalog, January 2018, https://data.worldbank.org/data-catalog.

Verikios, G. (2015), 'The implications for trade and FDI flows from liberalisation of China's capital account', Centre of Policy Studies Working Paper No. G-251, Victoria University, January.

Zhang, L., Zhang, S., Tao, N. (2016), 'Financial system risk tolerance capacity and economic growth: evidence from a cross-country analysis', Global Economic Review, vol. 45, no. 2,pp. 97-115. 